\title{
OPTIMASI JALUR EVAKUASI BAGI PEJALAN KAKI MENGGUNAKAN ALGORITMA FUZZY DIJKSTRA DI KECAMATAN TELUK SEGARA, BENGKULU
}

\section{Optimization of Evacuation Route for Pedestrians Using Fuzzy Dijkstra Algorithm in Teluk Segara District, Bengkulu}

\author{
Zulfia Memi Mayasari $^{1 *}$, Nur Afandi ${ }^{2}$ \\ 1,2 Prodi Matematika, FMIPA, Universitas Bengkulu \\ Jln. WR. Supratman Kota Bengkulu, 38371, Indonesia \\ Corresponding author e-mail: 1*zulfiamm@unib.ac.id
}

\begin{abstract}
Abstrak
Provinsi Bengkulu terletak di pesisir barat Pulau Sumatera dan tepat berada di antara pertemuan dua lempeng dunia yang sangat aktif yaitu Lempeng Benua Eurasia dan Lempeng Samudra Indo-Australia. Hal ini menyebabkan Provinsi Bengkulu tergolong sebagai provinsi yang sangat rawan terhadap bencana gempa bumi dan tsunami. Penelitian ini mengkaji persoalan optimasi pencarian rute evakuasi tsunami. Tujuan penelitian ini adalah menentukan rute evakuasi dari tiap-tiap cluster yang telah dibentuk menuju tempat berkumpul yang telah ditentukan. Tiap-tiap cluster, titik berkumpul dan ruas jalan yang menghubungkannya dibentuk menjadi suatu graph jaringan jalan dimana cluster dan titik berkumpul diwakili oleh vertex dan ruas jalan diwakili oleh edge. Graph jaringan jalan ini diberi bobot dimana dalam penentuan bobotnya menggunakan logika fuzzy dengan mempertimbangkan beberapa parameter yaitu panjang jalan, lebar jalan, dan jumlah penduduk yang berpengaruh pada tingkat keramaian dan tingkat kemacetan. Penentuan rute optimalnya dilakukan dengan menggunakan algoritma Dijkstra. Berdasarkan hasil penelitian, diperoleh rute optimal dari tiap-tiap cluster menuju tempat berkumpul yang telah ditentukan.
\end{abstract}

Kata Kunci : Bengkulu, dijkstra, evakuasi, fuzzy, optimasi

\begin{abstract}
Bengkulu Province is located on the west coast of Sumatra Island and between the junction of two very active world plates, namely the Eurasian Continent Plate and the Indo-Australian Ocean Plate. This causes Bengkulu Province to be classified as a province that is very vulnerable to earthquakes and tsunamis. This research examines the optimization problem of finding a tsunami evacuation route. The purpose of this study is to determine the evacuation route from each cluster that has been formed to a predetermined assembly point. For each cluster, the assembly point and the roads are formed into a road network graph where the clusters and assembly points are represented by vertices and the roads are represented by edges. This road network graph is given a weight which in determining the weight using fuzzy logic by considering several parameters, namely road length, road width and the number of residents which affect the level of crowd and the level of congestion. Determination of the optimal route is solved using the Dijkstra algorithm. Based on the research results, the optimal route was obtained from each cluster to the assembly point.
\end{abstract}

Keywords: Bengkulu, dijkstra, evacuation, fuzzy, optimization.

Article info:

Submitted: 01 ${ }^{\text {st }}$ July $2021 \quad$ Accepted: $30^{\text {th }}$ August 2021

How to cite this article:

Z. M. Mayasari, and N. Afandi, "OPTIMASI JALUR EVAKUASI BAGI PEJALAN KAKI MENGGUNAKAN ALGORITMA FUZZY DIJKSTRA DI KECAMATAN TELUK SEGARA, BENGKULU”, BAREKENG: J. Il. Mat. \& Ter., vol. 15, no. 03, pp. 581-590, Sep. 2021.

This work is licensed under a Creative Commons Attribution-ShareAlike 4.0 International License. Copyright @ 2021 Zulfia Memi Mayasari, Nur Afandi 


\section{PENDAHULUAN}

Tsunami adalah gelombang laut yang disebabkan oleh gempa bumi, tanah longsor atau letusan gunung api yang terjadi di dasar laut. Dari kejadian tsunami yang pernah terjadi di Indonesia, gempa bumi merupakan penyebab utama [1]. Beberapa kejadian gempa bumi terjadi di Provinsi Bengkulu dan tergolong sebagai gempa bumi yang berpotensi tsunami, sehingga Provinsi Bengkulu dapat dikatakan sebagai salah satu provinsi yang sangat rentan terhadap bahaya gempa bumi dan tsunami.

Sebagai provinsi yang sangat rentan terhadap bahaya tsunami, pemerintah Provinsi Bengkulu harus melakukan perencanaan dan berbagai upaya untuk mengantisipasi dampak bahaya tsunami. Berbagai upaya dapat dilakukan, misalnya memberikan sosialisasi mengenai daerah rawan bencana, memberikan simulasi tanggap bencana kepada masyarakat, serta memberikan informasi jalur evakuasi kepada masyarakat untuk meminimalisisr kerugian akibat bencana ini. Dalam evakuasi, prinsip utama yang harus dilakukan adalah menjamin keselamatan penduduk ketika dilakukan evakuasi dari daerah berbahaya menuju daerah yang aman [2].

Penelitian mengenai jalur evakuasi di sebagian wilayah di Provinsi Bengkulu pernah dilakukan. Pada tahun 2014, [3] telah melakukan evaluasi terhadap jalur evakuasi di Kota Bengkulu menggunakan simulasi numerik. Lima skenario dilakukan, dan dapat disimpulkan bahwa jalur evakuasi harus disiapkan dengan baik terutama pada saat terjadi tsunami di masa yang akan datang. Pada tahun 2018, [4] menghasilkan model jalur evakuasi horizontal di sebagian wilayah pesisir Kota Bengkulu dengan menggunakan pendekatan riset operasi dengan Algoritma Flyod Warshall. Dalam penelitian ini, hasil yang diperoleh sudah merupakan jalur optimal berdasarkan waktu, jarak, dan kondisi jalan, namun belum mempertimbangkan pusat keramaian, kemacetan, dan jumlah masyarakat yang ada di wilayah penelitian. Teluk Segara merupakan salah satu kecamatan di Kota Bengkulu yang sangat rentan terhadap bahaya tsunami [5]. Menurut [6], di wilayah pesisir Bengkulu khususnya Kecamatan Teluk Segara terdapat 5 cluster dari 48 cluster yang membutuhkan waktu lebih dari 15 menit menuju titik berkumpul, dimana waktu 15 menit adalah waktu yang tersedia setelah peringatan dini tsunami yang ditetapkan pemerintah untuk sampai di tempat aman. Selain itu, terdapat 17 cluster yang rawan bahaya karena membutuhkan waktu lebih dari 10 menit menuju titik berkumpul. Sebagian cluster ini terletak di Kelurahan Sumur Meleleh dan Kampung Kelawi di Kecamatan Teluk Segara Kota Bengkulu. Waktu evakuasi didefinisikan sebagai waktu sisa yang diperlukan oleh pengungsi untuk melakukan evakuasi dari pengumuman peringatan dini tsunami yang dikeluarkan BMKG sampai gelombang tsunami tiba di pantai [7]. Penelitian mengenai perencanaan jalur evakuasi tsunami dengan menggunakan Algoritma Fuzzy Dijkstra di Kecamatan Teluk Segara dan sekitarnya, pernah dilakukan oleh [8] namun hanya mempertimbangkan dua parameter yaitu panjang jalan dan lebar jalan.

Pada penelitian ini dibuat suatu perencanaan jalur evakuasi tsunami di Kecamatan Teluk Segara dan sekitarnya, dimana penentuan jalur tercepatnya menggunakan Algoritma Dijkstra dan dalam penentuan tingkat preferensinya menggunakan logika fuzzy. Proses penentuan rute terpendek dengan menggunakan Algoritma Dijkstra dapat dilihat dalam [9], [10], [11] dan [12], sedangkan cara menentukan tingkat preferensi menggunakan logika fuzzy dapat dilihat dalam [13], [14] dan [15]. Perencanaan jalur evakuasi dalam penelitian ini dispesifikasikan untuk kejadian pada siang hari, karena itu parameter yang dijadikan pertimbangan menjadi lebih banyak, di antaranya panjang jalan, lebar jalan dan jumlah masyarakat yang berpengaruh terhadap tingkat keramaian dan tingkat kemacetan. Tujuannya untuk mendapatkan jalur evakuasi opimal agar dapat meminimalisir risiko masyarakat terhadap bahaya tsunami.

\section{METODE PENELITIAN}

Penelitian ini dilakukan untuk mendapatkan model jalur evakuasi yang terbaik berdasarkan waktu kejadian siang hari dengan mempertimbangkan panjang jalan, lebar jalan dan jumlah masyarakat yang ada di Kecamatan Teluk Segara dan sekitarnya. Penentuan rute dilakukan dengan menggunakan Algoritma Dijkstra dengan bantuan bahasa pemrograman Matlab sedangkan penentuan tingkat preferensinya menggunakan logika fuzzy. Tahapan kegiatan yang dilakukan adalah:

\subsection{Observasi dan Mengumpulkan Data Penelitian}

Pada tahap ini dilakukan kegiatan observasi dan pengumpulan data baik data primer maupun data sekunder. Data primer didapat dari survey langsung ke lokasi penelitian untuk mendapatkan data tentang wilayah pemukiman, sedangkan pengumpulan data sekunder dilakukan melalui penelusuran berbagai pustaka yang 
ada. Data yang dikumpulkan berupa: (a) jaringan jalan yang didapat dari peta jaringan jalan Kota Bengkulu, (b) titik berkumpul, (c) lebar jalan, (d) panjang jalan, (e) jumlah penduduk di wilayah penelitian, (f) Jumlah siswa di setiap sekolah di wilayah penelitian, (g) Jumlah mahasiswa di setiap perguruan tinggi di wilayah penelitian dan (h) Jumlah penduduk yang berada di pasar di wilayah penelitian.

\subsection{Membuat Graph Jaringan Jalan}

Graph jaringan jalan dibuat berdasarkan cluster yang telah dibentuk, titik berkumpul dan ruas jalan. Cluster dan titik berkumpul direpresentasikan sebagai vertex, sedangkan ruas jalan direpresentasikan sebagai edge.

\subsection{Memberi Bobot Graph Berdasarkan Output Fuzzy}

Graph jaringan jalan yang telah dibentuk pada tahap sebelumnya diberi bobot berdasarkan output fuzzy yang dalam penentuan bobot ini mempertimbangkan panjang jalan, lebar jalan dan jumlah masyarakat.

\subsection{Merancang Jalur Evakuasi Tsunami}

Dari graph jaringan jalan yang telah diberi bobot, dibuat jalur evakuasi dari masing-masing cluster menuju tempat berkumpul yang telah ditetapkan. Penentuan jalur evakuasi dilakukan dengan menggunakan Algoritma Dijkstra dengan bantuan bahasa pemrograman matlab.

\subsection{Analisis Jalur Evakuasi}

Jalur evakuasi yang telah dihasilkan, diuji dan dianalisis berdasarkan data yang ada dan divalidasi berdasarkan kondisi di lapangan.

\section{HASIL DAN PEMBAHASAN}

Pada penelitian ini dibentuk 47 cluster dengan 3 titik berkumpul yang telah ditetapkan pemerintah. Berdasarkan cluster, titik berkumpul, dan ruas-ruas jalan yang berhubungan, dibentuk suatu graph jaringan jalan. Data 47 cluster, 3 titik berkumpul, panjang jalan, lebar jalan, dan graph jaringan jalan yang terbentuk dapat dilihat pada [8]. Titik berkumpul tersebut adalah titik berkumpul Kampung Kelawi, Alun-Alun Kota Bengkulu, dan Masjid At-Taqwa. Jumlah penduduk berbanding terbalik dengan kecepatan waktu evakuasi. Maksudnya, jika jumlah penduduk banyak maka jalanan menjadi ramai dan pergerakan penduduk menjadi lambat sehingga waktu dalam mengevakuasi penduduk menjadi lebih lama. Jumlah penduduk yang diperhitungkan dalam penelitian ini adalah jumlah penduduk yang tinggal di lokasi penelitian, jumlah murid di tiap sekolah di wilayah penelitian, jumlah mahasiswa di perguruan tinggi dan jumlah penduduk yang ada di pasar. Penghitungan jumlah penduduk pada siang hari diasumsikan $50 \%$ dari jumlah penduduk karena sisanya dianggap melakukan kegiatan/aktivitas di luar rumah [16]. Penghitungan jumlah penduduk yang berada di pasar mengikuti [16] yang diasumsikan sebagai: 20\% (kapasitas) $\times$ luas pasar/ 7,6 (kebutuhan ruang). Penghitungan jumlah murid yang ada di sekolah diperoleh berdasarkan data dapodik, sedangkan penghitungan jumlah mahasiswa di perguruan tinggi diasumsikan sebagai $10 \%$ dari jumlah mahasiswa dan karyawan di perguruan tinggi. Dalam penelitian ini, jumlah karyawan di perkantoran diabaikan karena tidak terlalu banyak perkantoran yang ada di lokasi penelitian. Jumlah penduduk di masingmasing cluster pada siang hari di wilayah penelitian dapat dilihat pada Tabel 1, berikut:

Tabel 1. Data Jalan dan Jumlah Penduduk di Wilayah Penelitian

\begin{tabular}{lcrrlrlllr}
\hline Edge & $\begin{array}{c}\text { Nama } \\
\text { Jalan }\end{array}$ & $\begin{array}{c}\text { Jumlah } \\
\text { Pdd } \\
\text { (Jiwa) }\end{array}$ & Edge & $\begin{array}{c}\text { Nama } \\
\text { Jalan }\end{array}$ & $\begin{array}{c}\text { Jumlah } \\
\text { Pdd } \\
\text { (Jiwa) }\end{array}$ & Edge & $\begin{array}{c}\text { Nama } \\
\text { Jalan }\end{array}$ & $\begin{array}{c}\text { Jumlah } \\
\text { Pdd } \\
\text { (Jiwa) }\end{array}$ \\
\hline$v_{1} e p_{1}$ & Enggano & 1030 & $v_{15} v_{16}$ & $\begin{array}{l}\text { Kapten } \\
\text { Syahrial }\end{array}$ & 306 & $v_{31} v_{34}$ & Veteran & 220 \\
\hline$v_{1} v_{2}$ & Bencoolen & 113 & $v_{15} v_{17}$ & $\begin{array}{l}\text { Salim } \\
\text { Barubara }\end{array}$ & 318 & $v_{31} v_{36}$ & $\begin{array}{l}\text { Letkol } \\
\text { Santoso }\end{array}$ & 286 \\
\hline$v_{2} v_{3}$ & Ibnu Hajar & 223 & $v_{16} v_{17}$ & $\begin{array}{l}\text { Ahmad } \\
\text { Dahlan }\end{array}$ & 402 & $v_{31} v_{42}$ & Ahmad Yani & 316 \\
\hline
\end{tabular}




\begin{tabular}{|c|c|c|c|c|c|c|c|c|}
\hline$v_{2} v_{5}$ & $\begin{array}{l}\text { TP Kasim } \\
\text { Nasir }\end{array}$ & 33 & $v_{16} v_{31}$ & $\begin{array}{l}\text { Ahmad } \\
\text { Yani }\end{array}$ & 211 & $v_{32} v_{33}$ & Belato & 147 \\
\hline$v_{2} v_{21}$ & Bencoolen & 255 & $v_{17} v_{18}$ & $\begin{array}{l}\text { Ahmad } \\
\text { Dahlan }\end{array}$ & 260 & $v_{32} v_{38}$ & Pari & 463 \\
\hline$v_{3} v_{4}$ & $\begin{array}{l}\text { Nusirwan } \\
\text { Zainul }\end{array}$ & 195 & $v_{18} v_{19}$ & Khadijah & 513 & $v_{33} e p_{2}$ & $\begin{array}{l}\text { Prof Dr } \\
\text { Hazairin }\end{array}$ & 1360 \\
\hline$v_{3} v_{7}$ & Pratu Aidit & 1379 & $v_{18} v_{30}$ & Khadijah & 94 & $v_{33} v_{34}$ & Rejamat & 781 \\
\hline$v_{4} e p_{1}$ & Enggano & 418 & $v_{19} v_{20}$ & Khadijah & 175 & $v_{33} v_{37}$ & $\begin{array}{l}\text { Prof Dr } \\
\text { Hazairin }\end{array}$ & 120 \\
\hline$v_{4} v_{12}$ & Bali & 2455 & $v_{20} v_{21}$ & Benteng & 48 & $v_{34} v_{35}$ & $\begin{array}{l}\text { Iskandar } \\
\text { Baksir }\end{array}$ & 218 \\
\hline$v_{4} v_{47}$ & Sumatera & 1112 & $v_{20} v_{24}$ & Benteng & 163 & $v_{35} v_{37}$ & M Hasan 1 & 228 \\
\hline$v_{5} v_{6}$ & $\begin{array}{l}\text { TP Kasim } \\
\text { Nasir }\end{array}$ & 228 & $v_{21} v_{22}$ & Bencoolen & 48 & $v_{35} v_{39}$ & $\begin{array}{l}\text { Iskandar } \\
\text { Baksir }\end{array}$ & 252 \\
\hline$v_{5} v_{7}$ & $\begin{array}{l}\text { Sentot } \\
\text { Alibasyah }\end{array}$ & 530 & $v_{22} v_{23}$ & $\begin{array}{l}\text { Ahmad } \\
\text { Yani }\end{array}$ & 27 & $v_{36} v_{39}$ & $\begin{array}{l}\text { Letkol } \\
\text { Santoso }\end{array}$ & 120 \\
\hline$v_{6} v_{8}$ & $\begin{array}{l}\text { Letkol } \\
\text { Iskandar }\end{array}$ & 315 & $v_{22} v_{41}$ & Pariwisata & 940 & $v_{36} v_{43}$ & Cendrawasih & 498 \\
\hline$v_{6} v_{19}$ & $\begin{array}{l}\text { Letda Abu } \\
\text { Hanifah }\end{array}$ & 424 & $v_{23} v_{24}$ & $\begin{array}{l}\text { Ahmad } \\
\text { Yani }\end{array}$ & 11 & $v_{37} v_{38}$ & M Hasan & 38 \\
\hline$v_{7} v_{9}$ & $\begin{array}{l}\text { H. Moh } \\
\text { Zahab }\end{array}$ & 203 & $v_{23} v_{25}$ & Panjaitan & 348 & $v_{37} v_{40}$ & M Hasan & 279 \\
\hline$v_{7} v_{11}$ & $\begin{array}{l}\text { Sentot } \\
\text { Alibasyah }\end{array}$ & 195 & $v_{24} e p_{2}$ & $\begin{array}{l}\text { Ahmad } \\
\text { Yani }\end{array}$ & 101 & $v_{38} v_{41}$ & Kerapu & 188 \\
\hline$v_{8} v_{9}$ & $\begin{array}{l}\text { Iskandar } \\
11\end{array}$ & 266 & $v_{24} v_{25}$ & Pendakian & 205 & $v_{39} v_{40}$ & $\begin{array}{l}\text { Letkol } \\
\text { Santoso }\end{array}$ & 110 \\
\hline$v_{8} v_{15}$ & $\begin{array}{l}\text { Letkol } \\
\text { Iskandar }\end{array}$ & 510 & $v_{24} v_{28}$ & Kol Berlian & 220 & $v_{40} e p_{3}$ & $\begin{array}{l}\text { Soekarno } \\
\text { Hatta }\end{array}$ & 175 \\
\hline$v_{9} v_{10}$ & $\begin{array}{l}\text { Lettu } \\
\text { Zulkifli }\end{array}$ & 285 & $v_{25} v_{26}$ & Panjaitan & 188 & $v_{40} v_{41}$ & Kerapu & 58 \\
\hline$v_{10} v_{11}$ & $\begin{array}{l}\text { Lettu } \\
\text { Zulkifli }\end{array}$ & 50 & $v_{26} v_{27}$ & Arraw & 388 & $v_{42} v_{43}$ & Suprapto & 219 \\
\hline$v_{10} v_{14}$ & $\begin{array}{l}\text { Lettu } \\
\text { Zulkifli }\end{array}$ & 224 & $v_{26} v_{28}$ & Pasar Ikan & 310 & $v_{42} v_{44}$ & Suprapto & 632 \\
\hline$v_{11} v_{12}$ & $\begin{array}{l}\text { Sentot } \\
\text { Alibasyah }\end{array}$ & 874 & $v_{27} v_{28}$ & Kol Berlian & 662 & $v_{43} v_{44}$ & Suprapto & 475 \\
\hline$v_{12} v_{13}$ & $\begin{array}{l}\text { MT } \\
\text { Haryono }\end{array}$ & 758 & $v_{27} v_{32}$ & Arraw & 414 & $v_{44} e p_{3}$ & $\begin{array}{l}\text { Soekarno } \\
\text { Hatta }\end{array}$ & 1584 \\
\hline$v_{12} v_{46}$ & Jawa & 178 & $v_{28} e p_{2}$ & $\begin{array}{l}\text { Prof Dr } \\
\text { Hazairin }\end{array}$ & 38 & $v_{44} v_{45}$ & $\begin{array}{l}\text { Basuki } \\
\text { Rahmat }\end{array}$ & 670 \\
\hline$v_{13} v_{14}$ & $\begin{array}{l}\text { Letkol } \\
\text { Iskandar }\end{array}$ & 221 & $v_{29} e p_{2}$ & $\begin{array}{l}\text { Ahmad } \\
\text { Yani }\end{array}$ & 553 & $v_{45} v_{46}$ & Bangka & 1204 \\
\hline$v_{13} v_{16}$ & $\begin{array}{l}\text { Jendral } \\
\text { Sudirman }\end{array}$ & 1180 & $v_{29} v_{30}$ & $\begin{array}{l}\text { Ahmad } \\
\text { Yani }\end{array}$ & 49 & $v_{45} v_{47}$ & $\begin{array}{l}\text { Basuki } \\
\text { Rahmat }\end{array}$ & 662 \\
\hline$v_{13} v_{42}$ & $\begin{array}{l}\text { Jendral } \\
\text { Sudirman }\end{array}$ & 65 & $v_{29} v_{34}$ & Veteran & 457 & $v_{46} v_{47}$ & Jawa & 305 \\
\hline$v_{14} v_{15}$ & $\begin{array}{l}\text { Letkol } \\
\text { Iskandar }\end{array}$ & 738 & $v_{30} v_{31}$ & $\begin{array}{l}\text { Ahmad } \\
\text { Yani }\end{array}$ & 287 & & & \\
\hline
\end{tabular}


Jaringan jalan yang terbentuk dari verteks-verteks ini ditunjukkan seperti pada Gambar 1, berikut:

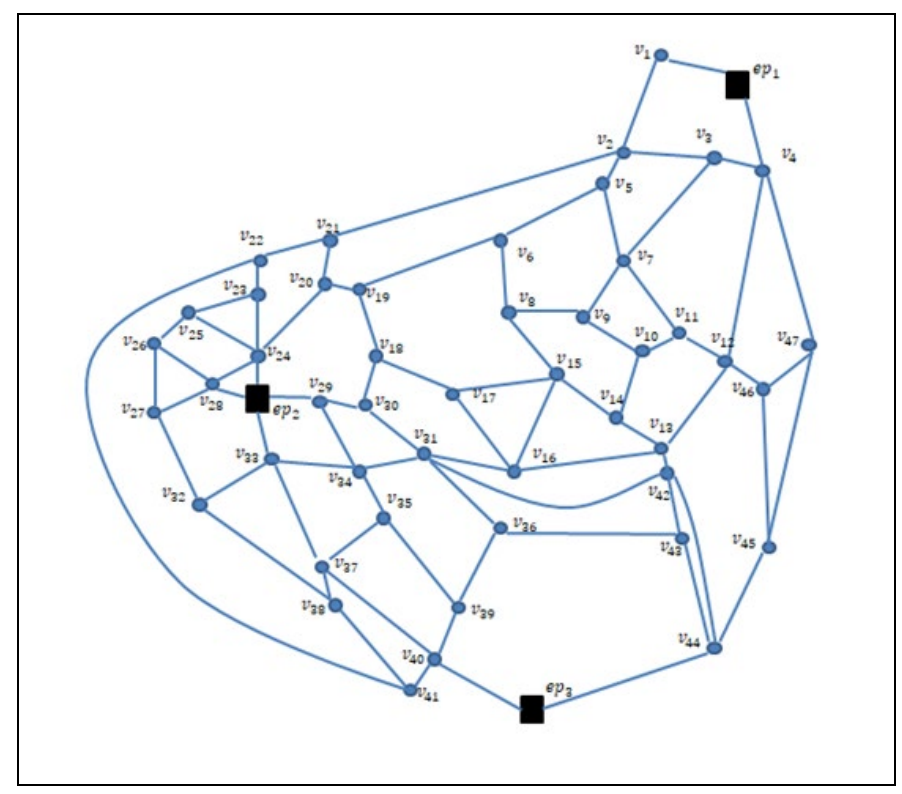

Gambar 1. Graph Jaringan Jalan di Wilayah Penelitian Sumber: [8]

Pembobotan graph jaringan jalan pada Gambar 1, menggunakan bilangan fuzzy triangular dengan fungsi keanggotaan sebagai berikut:

a. Fungsi keanggotaan untuk panjang jalan

$\mu_{L}$ pendek $(x)=\left\{\begin{array}{cc}1, & x \leq 100 \\ \frac{500-x}{500-100}, & 100<x<500 \\ 0, & x \geq 500\end{array}\right.$

$\mu_{L}$ sedang $(x)=\left\{\begin{array}{cc}\frac{x-100}{500-100}, & 100<x \leq 500 \\ \frac{1000-x}{1000-500}, & 500<x<1000 \\ 0, & x \geq 1000\end{array}\right.$

$\mu_{L}$ panjang $(x)=\left\{\begin{array}{cc}1, & x \geq 1000 \\ \frac{x-500}{1000-500}, & 500<x<1000 \\ 0, & x \leq 500\end{array}\right.$

b. Fungsi keanggotaan untuk lebar jalan

$$
\begin{aligned}
& \mu_{W} \text { sempit }(x)=\left\{\begin{array}{cc}
1, & x \leq 3 \\
\frac{5-x}{5-3}, & 3<x<5 \\
0, & x \geq 5
\end{array}\right. \\
& \mu_{W} \text { sedang }(x)=\left\{\begin{array}{cc}
\frac{x-3}{500-100}, & 3<x \leq 5 \\
\frac{13-x}{13-5}, & 5<x<13 \\
0, & x \geq 13
\end{array}\right.
\end{aligned}
$$


$\mu_{W}$ lebar $(x)=\left\{\begin{array}{cc}1, & x \geq 13 \\ \frac{x-5}{13-5}, & 5<x<13 \\ 0, & x \leq 3\end{array}\right.$

c. Fungsi keanggotaan untuk jumlah penduduk

$$
\begin{aligned}
& \mu_{p} \text { sedikit }(x)=\left\{\begin{array}{cc}
\frac{1,}{242-x} & x \leq 10 \\
242-10 & 10<x<242
\end{array}\right. \\
& \mu_{p} \text { sedang }(x)=\left\{\begin{array}{cc}
\frac{x-147}{242-147}, & 147<x \leq 242 \\
\frac{457-x}{457-242}, & 242<x \leq 457 \\
0, & x \leq 147 \text { atau } x \geq 457
\end{array}\right. \\
& \mu_{p} \text { banyak }(x)=\left\{\begin{array}{cc}
\frac{x-242}{1438-242}, & 242<x<1438 \\
0, & x \leq 242
\end{array}\right.
\end{aligned}
$$

Penentuan output fuzzy didasarkan pada aturan berikut:

- $\quad$ JIKA panjang jalan pendek DAN lebar jalan lebar DAN jumlah penduduk sedikit MAKA tingkat kecepatan 0,1

- JIKA panjang jalan pendek DAN lebar jalan lebar DAN jumlah penduduk sedang MAKA tingkat kecepatan 0,2

- JIKA panjang jalan pendek DAN lebar jalan lebar DAN jumlah penduduk banyak MAKA tingkat kecepatan 0,3

- $\quad$ JIKA panjang jalan pendek DAN lebar jalan sedang DAN jumlah penduduk sedikit MAKA tingkat kecepatan 0,2

- $\quad$ JIKA panjang jalan pendek DAN lebar jalan sedang DAN jumlah penduduk sedang MAKA tingkat kecepatan 0,3

- $\quad$ JIKA panjang jalan pendek DAN lebar jalan sedang DAN jumlah penduduk banyak MAKA tingkat kecepatan 0,4

- $\quad$ JIKA panjang jalan pendek DAN lebar jalan sempit DAN jumlah penduduk sedikit MAKA tingkat kecepatan 0,3

- $\quad$ JIKA panjang jalan pendek DAN lebar jalan sempit DAN jumlah penduduk sedang MAKA tingkat kecepatan 0,4

- $\quad$ JIKA panjang jalan pendek DAN lebar jalan sempit DAN jumlah penduduk banyak MAKA tingkat kecepatan 0,5

- $\quad$ JIKA panjang jalan sedang DAN lebar jalan lebar DAN jumlah penduduk sedikit MAKA tingkat kecepatan 0,3

- JIKA panjang jalan sedang DAN lebar jalan lebar DAN jumlah penduduk sedang MAKA tingkat kecepatan 0,4

- JIKA panjang jalan sedang DAN lebar jalan lebar DAN jumlah penduduk banyak MAKA tingkat kecepatan 0,5

- $\quad$ JIKA panjang jalan sedang DAN lebar jalan sedang DAN jumlah penduduk sedikit MAKA tingkat kecepatan 0,4

- $\quad$ JIKA panjang jalan sedang DAN lebar jalan sedang DAN jumlah penduduk sedang MAKA tingkat kecepatan 0,5

- $\quad$ JIKA panjang jalan sedang DAN lebar jalan sedang DAN jumlah penduduk banyak MAKA tingkat kecepatan 0,6

- JIKA panjang jalan sedang DAN lebar jalan sempit DAN jumlah penduduk sedikit MAKA tingkat kecepatan 0,5 
- $\quad$ JIKA panjang jalan sedang DAN lebar jalan sempit DAN jumlah penduduk sedang MAKA tingkat kecepatan 0,6

- $\quad$ JIKA panjang jalan sedang DAN lebar jalan sempit DAN jumlah penduduk banyak MAKA tingkat kecepatan 0,7

- $\quad$ JIKA panjang jalan panjang DAN lebar jalan lebar DAN jumlah penduduk sedikit MAKA tingkat kecepatan 0,5

- $\quad$ JIKA panjang jalan panjang DAN lebar jalan lebar DAN jumlah penduduk sedang MAKA tingkat kecepatan 0,6

- $\quad$ JIKA panjang jalan panjang DAN lebar jalan lebar DAN jumlah penduduk banyak MAKA tingkat kecepatan 0,8

- $\quad$ JIKA panjang jalan panjang DAN lebar jalan sedang DAN jumlah penduduk sedikit MAKA tingkat kecepatan 0,6

- $\quad$ JIKA panjang jalan panjang DAN lebar jalan sedang DAN jumlah penduduk sedang MAKA tingkat kecepatan 0,7

- $\quad$ JIKA panjang jalan panjang DAN lebar jalan sedang DAN jumlah penduduk banyak MAKA tingkat kecepatan 0,9

- $\quad$ JIKA panjang jalan panjang DAN lebar jalan sempit DAN jumlah penduduk sedikit MAKA tingkat kecepatan 0,7

- $\quad$ JIKA panjang jalan panjang DAN lebar jalan sempit DAN jumlah penduduk sedang MAKA tingkat kecepatan 0,8

- $\quad$ JIKA panjang jalan panjang DAN lebar jalan sempit DAN jumlah penduduk banyak MAKA tingkat kecepatan 1,0

Berdasarkan fungsi keanggotaan untuk panjang jalan, lebar jalan dan jumlah penduduk serta aturan penentuan output fuzzy yang telah ditentukan, diperoleh tingkat kecepatan evakuasi seperti yang ditunjukkan pada Tabel 2, berikut:

Tabel 2. Output Fuzzy Berupa Tingkat Kecepatan Evakuasi

\begin{tabular}{|c|c|c|c|c|c|c|c|c|c|}
\hline Edge & $\begin{array}{l}\text { Output } \\
\text { Fuzzy }\end{array}$ & Edge & $\begin{array}{c}\text { Output } \\
\text { Fuzzy }\end{array}$ & Edge & $\begin{array}{c}\text { Output } \\
\text { Fuzzy }\end{array}$ & Edge & $\begin{array}{c}\text { Output } \\
\text { Fuzzy }\end{array}$ & Edge & $\begin{array}{c}\text { Output } \\
\text { Fuzzy }\end{array}$ \\
\hline$v_{1} e p_{1}$ & 0,57 & $v_{8} v_{15}$ & 0,55 & $v_{18} v_{30}$ & 0,29 & $v_{28} e p_{2}$ & 0,39 & $v_{36} v_{43}$ & 0,55 \\
\hline$v_{1} v_{2}$ & 0,30 & $v_{9} v_{10}$ & 0,47 & $v_{19} v_{20}$ & 0,30 & $v_{29} e p_{2}$ & 0,21 & $v_{37} v_{38}$ & 0,40 \\
\hline$v_{2} v_{3}$ & 0,50 & $v_{10} v_{11}$ & 0,31 & $v_{20} v_{21}$ & 0,30 & $v_{29} v_{34}$ & 0,42 & $v_{37} v_{40}$ & 0,38 \\
\hline$v_{2} v_{5}$ & 0,28 & $v_{10} v_{14}$ & 0,46 & $v_{20} v_{24}$ & 0,39 & $v_{29} v_{31}$ & 0,28 & $v_{38} v_{41}$ & 0,47 \\
\hline$v_{2} v_{21}$ & 0,70 & $v_{11} v_{12}$ & 0,51 & $v_{21} v_{22}$ & 0,27 & $v_{30} v_{31}$ & 0,45 & $v_{39} v_{40}$ & 0,39 \\
\hline$v_{3} v_{4}$ & 0,31 & $v_{12} v_{13}$ & 0,41 & $v_{22} v_{23}$ & 0,14 & $v_{31} v_{34}$ & 0,40 & $v_{40} e p_{3}$ & 0,25 \\
\hline$v_{3} v_{7}$ & 0,63 & $v_{12} v_{46}$ & 0,25 & $v_{22} v_{41}$ & 0,89 & $v_{31} v_{36}$ & 0,44 & $v_{40} v_{41}$ & 0,35 \\
\hline$v_{4} e p_{1}$ & 0,54 & $v_{13} v_{14}$ & 0,40 & $v_{23} v_{24}$ & 0,19 & $v_{31} v_{42}$ & 0,55 & $v_{42} v_{43}$ & 0,23 \\
\hline$v_{4} v_{12}$ & 0,57 & $v_{13} v_{16}$ & 0,52 & $v_{23} v_{25}$ & 0,45 & $v_{32} v_{33}$ & 0,45 & $v_{42} v_{44}$ & 0,50 \\
\hline$v_{4} v_{47}$ & 0,53 & $v_{13} v_{42}$ & 0,14 & $v_{24} e p_{2}$ & 0,18 & $v_{32} v_{38}$ & 0,51 & $v_{43} v_{44}$ & 0,46 \\
\hline$v_{5} v_{6}$ & 0,45 & $v_{14} v_{15}$ & 0,54 & $v_{24} v_{25}$ & 0,42 & $v_{33} e p_{2}$ & 0,46 & $v_{44} e p_{3}$ & 0,85 \\
\hline$v_{5} v_{7}$ & 0,55 & $v_{15} v_{16}$ & 0,48 & $v_{24} v_{28}$ & 0,33 & $v_{33} v_{34}$ & 0,49 & $v_{44} v_{45}$ & 0,65 \\
\hline$v_{6} v_{8}$ & 0,45 & $v_{15} v_{17}$ & 0,47 & $v_{25} v_{26}$ & 0,39 & $v_{33} v_{37}$ & 0,45 & $v_{45} v_{46}$ & 0,85 \\
\hline$v_{6} v_{19}$ & 0,56 & $v_{16} v_{17}$ & 0,53 & $v_{26} v_{27}$ & 0,41 & $v_{34} v_{35}$ & 0,32 & $v_{45} v_{47}$ & 0,76 \\
\hline$v_{7} v_{9}$ & 0,44 & $v_{16} v_{31}$ & 0,30 & $v_{26} v_{28}$ & 0,48 & $v_{35} v_{37}$ & 0,38 & $v_{46} v_{47}$ & 0,41 \\
\hline$v_{7} v_{11}$ & 0,42 & $v_{17} v_{18}$ & 0,49 & $v_{27} v_{28}$ & 0,38 & $v_{35} v_{39}$ & 0,46 & & \\
\hline$v_{8} v_{9}$ & 0,48 & $v_{18} v_{19}$ & 0,55 & $v_{27} v_{32}$ & 0,55 & $v_{36} v_{39}$ & 0,45 & & \\
\hline
\end{tabular}

Output fuzzy yang diperoleh pada Tabel 2, digunakan sebagai bobot dari graph pada Gambar 1 . Selanjutnya untuk menentukan rute jalur evakuasi dari masing-masing cluster menuju titik berkumpul digunakan Algoritma Dijkstra yang prosedurnya dapat dilihat dalam [9], [10], [11] dan [12] sehingga diperoleh rute seperti pada Gambar 2, berikut. 


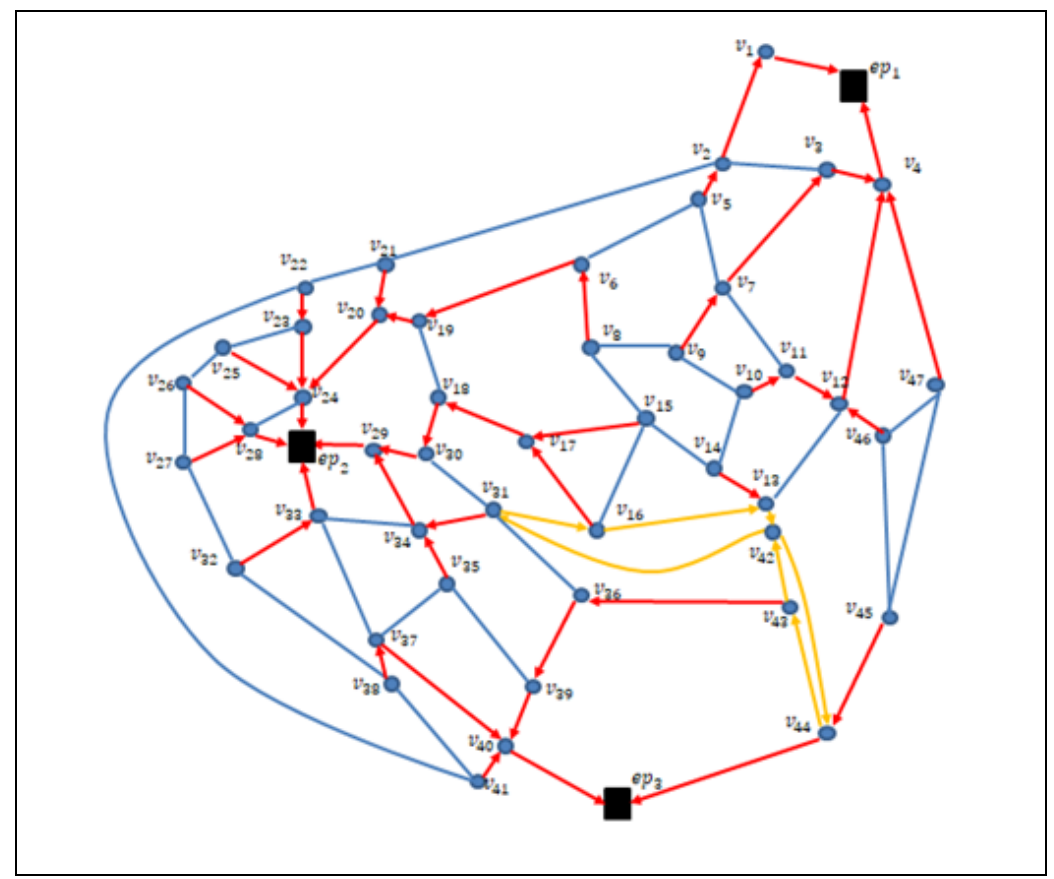

Gambar 2. Jalur Evakuasi untuk Kejadian Siang Hari

Berdasarkan hasil gambar diatas terdapat 21 rute untuk jalur evakuasi dengan rincian, sebagai berikut:

a. Lima rute menuju titik kumpul Kampung Kelawi $\left(e p_{1}\right)$ yaitu:

$v_{5}-v_{2}-v_{1}-e p_{1}$ dengan total bobot 155

$v_{9}-v_{7}-v_{3}-v_{4}-e p_{1}$ dengan total bobot 192

$v_{10}-v_{11}-v_{12}-v_{4}-e p_{1}$ dengan total bobot 193

$v_{46}-v_{12}-v_{4}-e p_{1}$ dengan total bobot 136

$v_{47}-v_{4}-e p_{1}$ dengan total bobot 107

b. Sepuluh rute menuju titik kumpul Alun-alun Kota Bengkulu $\left(e p_{2}\right)$ yaitu:

$v_{8}-v_{6}-v_{19}-v_{20}-v_{24}-e p_{2}$ dengan total bobot 188

$v_{15}-v_{17}-v_{18}-v_{30}-v_{29}-e p_{2}$ dengan total bobot 188

$v_{16}-v_{17}-v_{18}-v_{30}-v_{29}-e p_{2}$ dengan total bobot 201

$v_{21}-v_{22}-v_{23}-v_{24}-e p_{2}$ dengan total bobot 78

$v_{25}-v_{24}-e p_{2}$ dengan total bobot 60

$v_{26}-v_{28}-e p_{2}$ dengan total bobot 87

$v_{27}-v_{28}-e p_{2}$ dengan total bobot 77

$v_{31}-v_{34}-v_{29}-e p_{2}$ dengan total bobot 89

$v_{32}-v_{33}-e p_{2}$ dengan total bobot 91

$v_{35}-v_{34}-v_{29}-e p_{2}$ dengan total bobot 81

c. Enam rute menuju titik kumpul Masjid At Taqwa $\left(e p_{3}\right)$ yaitu:

$v_{14}-v_{13}-v_{42}-v_{44}-e p_{3}$ dengan total bobot 189

$v_{16}-v_{13}-v_{42}-v_{44}-e p_{3}$ dengan total bobot 201

$v_{38}-v_{37}-v_{40}-e p_{3}$ dengan total bobot 103

$v_{41}-v_{40}-e p_{3}$ dengan total bobot 60

$v_{43}-v_{36}-v_{39}-v_{49}-e p_{3}$ dengan total bobot 164

$v_{45}-v_{44}-e p_{3}$ dengan total bobot 150

\section{KESIMPULAN}

Jalur evakuasi yang dihasilkan pada penelitian ini merupakan jalur optimal untuk kejadian siang hari. Penentuan jalur ini dengan mempertimbangkan berbagai faktor, di antaranya panjang jalan, lebar jalan dan jumlah penduduk yang berpengaruh pada tingkat kemacetan dan tingkat keramaian. 


\section{UCAPAN TERIMA KASIH}

Terima kasih disampaikan kepada FMIPA Universitas Bengkulu yang telah mendanai penelitian ini melalui skim Penelitian Unggulan FMIPA Universitas Bengkulu Tahun 2020 dengan No. Kontrak 2049/ $\mathrm{UN} 30.12 / \mathrm{HK} / 2020$.

\section{DAFTAR PUSTAKA}

[1] N. T. Puspito and W. Triyoso, Aspek Kegempaan Tsunami di Indonesia: Suatu Tinjauan Awal. Bandung. 1994.

[2] R. S. Dewi, A-Gis Based Approach to the Selection of Evacuation Shelter Buildings and Routes Ttsunami Risk Reduction: A Case Study of Cilacap Coastal Area Indonesia, [Thesis] Gadjah Mada University, University of Twente, 2010. [Online]

[3] R. Triatmadja and S. S. Nasution, Evalution of tsunami evacuation routes at bengkulu city indonesia using numerical simulations, ASEAN Engineering Journal, vol.3, no.2, pp.9-20, December 2014.

[4] Z. M. Mayasari, U. Rafflesia, M. Astuti and Y. Fauzi, Mathematical modelling approach of an evacuation model for tsunami risk reduction in bengkulu, Journal of Physics: Conference Series, 1188, 012094, 2019.

[5] Y. Fauzi, Suwarsono and Z. M. Mayasari, The run up modelling in Bengkulu using the spatial interpolation of kriging technique, Forum Geografi, vol.28, no.2, pp.103-112, December 2014.

[6] Z. M. Mayasari, U. Rafflesia and M. Astuti, Pemodelan Matematika untuk Sistem Evakuasi Tsunami Kota Bengkulu Menggunakan Algoritma Flyod Warshall (Studi Kasus: Sebagian Wilayah Pesisir Kota Bengkulu), Laporan Penelitian Unggulan Universitas Bengkulu, Tidak dipublikasikan. 2018.

[7] BNPB, Kajian Risiko Bencana Tsunami. Jakarta, BNPB. 2011

[8] N. Afandi dan Z.M. Mayasari, An evacuation route in bengkulu city based on fuzzy dijkstra algorithm. Journal of Physics: Conference Series, 1863, 012007, 2021.

[9] Y. Z. Chen, S. F. Shen, T. Chen and R. Yang, Path optimization study for vehicles evacuation based on dijkstra algorithm. Procedia Engineering, vol.71, pp.159 - 165, December 2014.

[10] I. W. Sudarsana, S. Mendi, Abdullah, A. Hendra and A. Sahari, Model matematika untuk sistem evakuasi kota palu (SET_KP) berbasis jalur terpendek dan waktu evakuasi minimum, Online Jurnal of Natural Science, vol.2, no.3, pp.39-53, Desember 2013.

[11] S. Ardyan, Mulyono and A. Suyitno, Implementasi algoritma dijkstra dalam pencarian rute terpendek tempat wisata di kabupaten gunung kidul dengan program visual basic, Unnes Journal of Mathematics, vol.6 no.2, pp 108-116, November 2017.

[12] I. H. A. Amin, V. Lusiana and B. Hartono, Visualisasi pencarian lintasan terpendek algoritma floyd-warshall dan dijkstra menggunakan TEX, Prosiding SINTAK, pp 17-23, 2017.

[13] Y. Deng, Y. Chen, Y. Zhang and S. Mahadevan, Fuzzy Dijkstra algorithm for shortest path problem under uncertain environment, Applied Soft Computing, vol.12, no.3, pp.1231-1237, March 2012.

[14] N. Nggufron, Rochmad and Mashuri, Pencarian rute terbaik pemadam kebakaran kota semarang menggunakan algoritma dijkstra dengan logika fuzzy sebagai penentu bobot pada graf. Unnes Journal of mathematics, vol.8, no.1, pp.40-49, Juni 2019.

[15] M. H. H. Ichsan, E. Yudaningtyas and M.A. Muslim, Solusi optimal pencarian jalur tercepat dengan algoritma hybrid fuzzydijkstra, Jurnal EECCIS, vol.6, no.2, pp.155-160, Desember 2012.

[16] A. Budiarjo, Evacuation shelter building planning for tsunami-prone area; a case study of Meulaboh City, Indonesia. [Thesis], Intrenational Institute for Geo-Information Science and Earth Observation Enschede Nedherlands, 2006. [Online]. 
